\title{
BioLink
}

Jurnal Biologi Lingkungan, Industri, Kesehatan

Available online http://ojs.uma.ac.id/index.php/biolink

\section{UTILIZATION OF PAPAYA LEAVES (CARICA PAPAYA L.) TO CONTROL ONION PEST SPODOPTERA EXIGUA (LEPIDOPTERA: NOCTUIDAE)LEPIDOPTERA (NOCTUIDAE)}

\section{Muhammad Agung Permadi*, Rafiqah Amanda Lubis, Syawaluddin, \& Nova Suryani Pasaribu}

Program Study Agrotechnology, Faculty of Agriculture, Universitas Muhammadiyah Tapanuli Selatan, Indonesia

Submited : 03-09-2019; Accepted : 13-02-2020: Published : 10-08-2020

*Corresponding author: E-mail : muhammad.agungp@um-tapsel.ac.id

\begin{abstract}
Spodoptera exigua is a migrant pest that attacks onions simultaneously in groups. The utilization of papaya leaves to control pests due to papaya leaves have toxic compounds that can kill pests. This study aims to measure the ability of papaya leaves to control S. exigua larvae. This research was conducted using a completely randomized design (CRD) experimental method with two treatment factors. The first factor was papaya leaf concentration $(0 \mathrm{~g} / \mathrm{l}, 30 \mathrm{~g} / \mathrm{l}, 70 \mathrm{~g} / \mathrm{l}, 100 \mathrm{~g} / \mathrm{l}, 120 \mathrm{~g} / \mathrm{l})$, and the second factor is a mixture of kerosene. The treatment was repeated three times. The study was conducted at the Agrotechnology Laboratory, Agriculture Faculty Muhammadiyah University, South Tapanuli. The results showed that papaya leaves could kill S. exigua larvae. The highest mortality of S. exigua worms There were statistically significant non-treatments among treatments.
\end{abstract}

Key Words: Mortality, larvae, pesticides, biological control

How to Cite: Permadi, M.A, Lubis, R.A, Syawaludin, \& Pasaribu, N.S. (2020). Utilization of Papaya Leaves (Carica papaya L.) to Control Onion Pest Spodoptera Exigua (Lepidoptera: Noctuidae)Lepidoptera (Noctuidae), BioLink: Jurnal Biologi Lingkungan, Industri dan Kesehatan, Vol.7 (1): Hal. 1- 7 
Permadi, M.A, Lubis, R.A, Syawaludin, \& Pasaribu, N.S.. Utilization of Papaya Leaves (Carica papaya L.) to Control Onion Pest Spodoptera Exigua (Lepidoptera: Noctuidae)Lepidoptera (Noctuidae)

\section{INTRODUCTION}

Spodoptera exigua is the primary pest of onion plants. These pests attack in groups and simultaneously. Putrasamedja et al., (2012) stated in their research, attack S. exigua can cause yield loss ranging from $57-100 \%$ if it strikes in the vegetative phase. Larvae $S$. exigua attacks by eating the edges of the leaf edges, especially young leaves so that the leaves appear transparent, cut into pieces (Fattah and Ilyas, 2016).

In general, farmers still use synthetic insecticides for pests $S$. exigua. However, the use of synthetic insecticides has a negative impact that is resistance, resurgence, death of natural enemies, residues in agricultural products, health problems for producers, consumers, and environmental pollution (Yuantari et al., 2015). One effort to reduce the use of synthetic pesticides is a method of vegetable control by utilizing plants that have toxic substances against pests.

Many plants and their parts can be extracted as raw materials for vegetable pesticides. One of the plants that can be used as vegetable pesticides is papaya, especially papaya leaves. Papaya leaves contain enzymes such as papain, tannin, flavonoids, and saponins (A'yun and Laily, 2015). Papaya leaf extract has been tested by several researchers to control various types of pests, including armyworm
Spodoptera litura in chili plants (Ningrum et al., 2015), Aphis gossypii on eggplant plants (Ramadhona et al., 2018), Crocidolomia binotalis and Plutella xylostella (Nikasari, 2013).

This study aims to utilize papaya leaves to control S. exigua through a simple process of processing plant-based pesticides.

\section{MATERIALS AND METHODS}

The study was conducted in MarchJuly 2019 in the laboratory of Program Studi Agroteknologi, Fakultas Pertanian, Universitas Muhammadiyah Tapanuli Selatan. The location of the retrieval of $S$. exigua in the Rimba Soping Village and Pintu Langit Padangsidimpuan City. The larvae obtained are kept in a laboratory for rearing.

The study was conducted using a completely randomized design (CRD) experimental method with two treatment factors. The first factor is the concentration of papaya leaves $(0,30,60,90,120 \mathrm{~g} / \mathrm{l})$, and the second factor is without the addition of kerosene and the addition of kerosene. The treatment was repeated three times. Each experimental unit consisted of 15 S. exigua instar III larvae. The results obtained were further tested with DMRT at the 5\% level.

Making a plant-based insecticide solution from papaya leaves based on Sari 
et al., (2013) each papaya leaves was weighed according to treatment. Papaya leaves are cut into small pieces and then ground using a blender, and $1 \mathrm{~L}$ of water is added. Then add $1 \mathrm{ml}$ of detergent. As for the second treatment factor, $28 \mathrm{ml}$ of kerosene was added, and $1 \mathrm{ml}$ of soap in each treatment. Then the solution is put into a bottle, tightly closed, and allowed to stand for 24 hours. The next day the solution is filtered with a filter.

The treatment was carried out using the feed dip method. Each leek is cut $5 \mathrm{~cm}$ in size, then dipped for 30 seconds in each container that already contains various concentrations of papaya leaves solution.
Dipped scallions are dried and put in a petri dish as feed $S$. exigua. The treatment was carried out once, on the first day.

Observation parameters were the mortality percentage of larvae $S$. exigua, lethal time 50 (LT50), and lethal concentrate 50 (LC50).

\section{RESULTS AND DISCUSSION}

The results showed that the application of papaya leaves caused the mortality of third instar larvae $S$. exigua. Mortality S. exigua without the addition of kerosene and the addition of kerosene showed no significant effect (Table 1).

Table 1. Percentage average mortality of larvae $S$. exigua due to the addition of kerosene.

\begin{tabular}{cc}
\hline Treatment of & Larval mortality (\%) \\
\hline Kerosene $0 \mathrm{ml} / \mathrm{L}$ & 71 \\
Kerosene $28 \mathrm{ml} / \mathrm{L}$ & 69.78
\end{tabular}

Table 2. Percentage average mortality of larvae $S$. exigua due to the influence of papaya leaves concentration

\begin{tabular}{cc}
\hline Papaya leaves concentration & Larval mortality (\%) \\
\hline $0 \mathrm{~g} / \mathrm{l}$ & $28,89 \mathrm{~b}$ \\
$30 \mathrm{~g} / \mathrm{l}$ & $87.78 \mathrm{a}$ \\
$70 \mathrm{~g} / \mathrm{l}$ & $77.78 \mathrm{a}$ \\
$100 \mathrm{~g} / \mathrm{l}$ & $83.33 \mathrm{a}$ \\
$120 \mathrm{gl} / \mathrm{l}$ & $76.67 \mathrm{a}$ \\
\hline
\end{tabular}

Note: Number followed by the same letter in the same column shows no significant difference according to the $5 \%$ DMRT Test.

The mortality of larvae is $S$. exigua due and $120 \mathrm{gr} / \mathrm{l}$ respectively caused the death to the application of papaya leaves of larvae S. exigua by $88.99 \%$ and $76.67 \%$. concentration did not show any significant (Table 2).

difference. The concentration of $30 \mathrm{~g} / \mathrm{l}$ 
Permadi, M.A, Lubis, R.A, Syawaludin, \& Pasaribu, N.S.. Utilization of Papaya Leaves (Carica papaya L.) to Control Onion Pest Spodoptera Exigua (Lepidoptera: Noctuidae)Lepidoptera (Noctuidae)

Table 3 Percentage average mortality of larvae $S$. exigua due to the influence of the concentration of papaya leaves and kerosene at seven days after application

\begin{tabular}{ccc}
\hline \multirow{2}{*}{ Papaya leaves concentration } & \multicolumn{2}{c}{ Larval mortality (\%) } \\
\cline { 2 - 3 } & Kerosene $0 \mathrm{ml} / \mathrm{l}$ & Kerosene $28 \mathrm{ml} / \mathrm{l}$ \\
\hline $0 \mathrm{gr} / \mathrm{L}$ & $15.56 \mathrm{c}$ & $42.22 \mathrm{~b}$ \\
$30 \mathrm{gr} / \mathrm{L}$ & $88.89 \mathrm{a}$ & $86.67 \mathrm{a}$ \\
$70 \mathrm{gr} / \mathrm{L}$ & $84.44 \mathrm{a}$ & $71.11 \mathrm{a}$ \\
$100 \mathrm{gr} / \mathrm{L}$ & $84.44 \mathrm{a}$ & $82.22 \mathrm{a}$ \\
$120 \mathrm{gr} / \mathrm{L}$ & $86,67 \mathrm{a}$ & $66.67 \mathrm{a}$ \\
\hline
\end{tabular}

Note: Numbers followed by the same letters in the same column show no significant difference according to the $5 \%$ DMRT Test.

In the table above, it can be seen that concentration and the addition of kerosene the mortality of larvae of III instar S. exigua does not show any significant difference. due to the treatment of papaya leaves

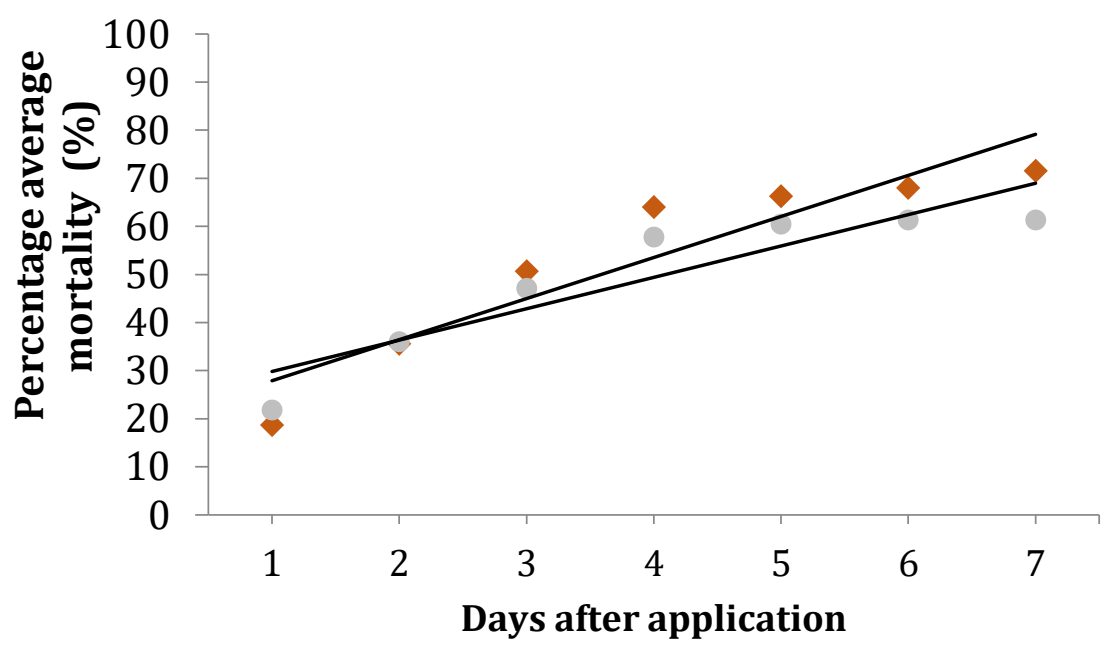

Figure 1 Probit (lethal time) papaya leaves concentration of larvae $S$. exigua (Note: $\downarrow=$ kerosene $0 \mathrm{ml} / \mathrm{L}, \cdot=$ kerosene $28 \mathrm{ml} / \mathrm{L}$ )

Table 4 LT 50 concentration of papaya leaves against instar III larvae S. exigua

\begin{tabular}{cc}
\hline Kerosene treatment & LT50 (DAA) \\
\hline $0 \mathrm{ml} / \mathrm{l}$ & 3.59 \\
$28 \mathrm{ml} / \mathrm{l}$ & 4.09 \\
\hline
\end{tabular}

Note: $\overline{D A A}=$ days after application 


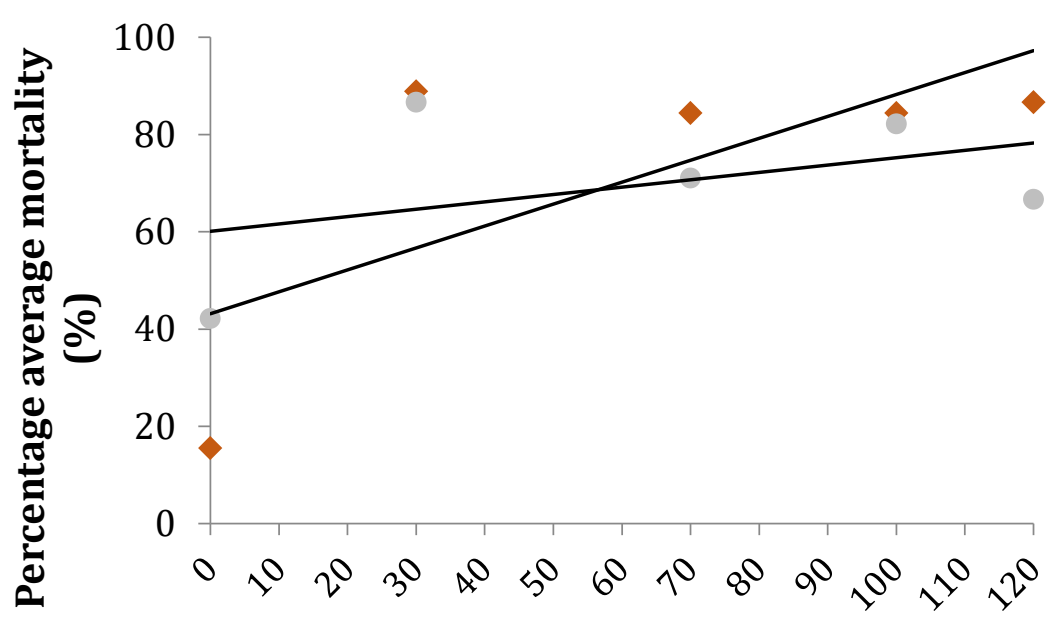

Concentration of papaya leaves (gr/L)

Figure 1 Mortality of probit (lethal concentrate) concentration of papaya leaves against larvae $S$. exigua (Note: $\diamond=$ kerosene $0 \mathrm{ml} / \mathrm{L}, \cdot=$ kerosene $28 \mathrm{ml} / \mathrm{L}$ )

Table 5 LC 50 Concentration of papaya leaves to kill instar larvae III S. exigua

\begin{tabular}{cc}
\hline Kerosene treatment & LC $50(\mathrm{gr} / \mathrm{L})$ \\
\hline $0 \mathrm{ml} / \mathrm{l}$ & 25.18 \\
$28 \mathrm{ml} / \mathrm{l}$ & 56.82 \\
\hline
\end{tabular}

Note: $\mathrm{DAA}=$ days after application

Papaya leaves will be more effective if leaves also contain alkaloids and flavonoids modified with other active compounds such that function as stomach poisons. These as detergent and kerosene (Hasfita et. Al., substances cause a decrease in feeding 2013). The addition of kerosene, according activities by instar larvae of $S$. exigua. Also, to (Sastroutomo, 1992), functions as an the treated larvae were seen to be less active solvent that also influences the active. This is by research Cahyadi (2009), activity of pesticides. However, in this namely alkaloids and flavonoids can study, kerosene addition did not have a function as stomach poisons. If the larvae significantly different effect on mortality of eat the compound, the digestive apparatus instar larvae S. exigua, when compared with the concentration of papaya solution without the addition of kerosene.

Papaya leaves have chemical contents such as tannin, saponin, and the enzyme papain (A'yun and Laily, 2015). Papaya of the worm will experience interference.

Cahyadi (2009) also states that flavonoid compounds contained in papaya leaves can inhibit the taste receptors in the mouth area of the larvae. This causes the worms not to be able to recognize their 
Permadi, M.A, Lubis, R.A, Syawaludin, \& Pasaribu, N.S.. Utilization of Papaya Leaves (Carica papaya L.) to Control Onion Pest Spodoptera Exigua (Lepidoptera: Noctuidae)Lepidoptera (Noctuidae)

food, resulting in inhibited eating activities and causes the larvae to starve to death. Besides, flavonoids can also damage nerves, especially in spiracles that cause insects unable to breathe and die.

In this study, the treatment without the addition of kerosene and the addition of kerosene showed no significant effect. In contrast to the research of Fachraniah et al. (2011) which states that the addition of supporting materials such as kerosene and detergents can increase the killing power of the insects tested.

Detergent is used as one of the ingredients because the soap has a compound that functions as an adhesive and is toxic, namely surfactant. Pratiwi (2011) states that a surfactant that works as an adhesive will turn into chlorobenzene, which has toxic properties that can kill insect pests. This is consistent with the statement of Fachraniah et al. (2011) who stated that detergent is Sodium salt which is from sulfonic acid, which contains alkyl benzene and sulfonate which has carcinogenic properties which can reduce pest insects.

The treatment of papaya leaves concentration without the addition of kerosene shows it can kill faster than the treatment of papaya leaf concentration with the addition of kerosene. This can be seen from the low LT50 value of each procedure, namely 3.59 days and 4.09 days, respectively. The treatment of papaya leaves also showed the lowest LC50 value without the addition of kerosene. The lower the LC50 cost, the more effective it is to kill pests.

\section{CONCLUSION}

Papaya leaves can be used as plantbased pesticides to control instar III larvae S. exigua without the addition of kerosene or by adding kerosene. Based on the results of research, the concentration of papaya leaves that able to kill instar III larvae $S$. exigua is $30 \mathrm{gr} / \mathrm{l}$. Kerosene can also kill instar III larvae S. exigua.

\section{REFERENCES}

A'yun, Q. \& Laily, A.N. 2015. Analisis Fitokimia Daun Pepaya (Carica papaya L.) Di Balai Penelitian Tanaman Aneka Kacang dan Umbi, Kendalpayak, Malang. Prosiding Seminar Nasional Konservasi dan Pemanfaatan Sumber Daya Alam. Surakarta 13 Januari 2015.

Cahyadi, R. (2009). Uji Toksisitas Akut Ekstrak Etanol Buah Pare (Momordica carantica L.) Terhadap Larva Artemia salina Leach dengan Metode Brine Shrimp Letrhality Test (BST) . Skripsi. Universitas Diponegoro.

Fachraniah, Kurniasih E., Azhar M. (2011). Pestisida alami dari daun dan batang pepaya Prosiding Seminar Nasional Yusuf Benseh 2012. Lhokseumawe (ID): Politeknik Negeri Lhokseumawe.

Fattah, A. \& Ilyas, A. 2016. Siklus Hidup Ulat Grayak (Spodoptera litura, F) dan Tingkat Serangan pada Beberapa Varietas Unggul Kedelai di Sulawesi Selatan. Prosiding Seminar Nasional Inovasi Teknologi Pertanian. Banjarbaru 20 Juli 2016. 
Hasfita F., Nasrul Z.A., Lafyati. 2013. Pemanfaatan daun pepaya (Carica Papaya) untuk Pembuatan Pestisida Nabati. Jurnal Teknologi Kimia Unimal. 1 (2): 13-24.

Nikasari, R.P. (2013). Uji Ekstrak Daun Pepaya (Carica papaya L) Terhadap Mortalitas Hama Ulat Titik Tumbuh (Crocidolomia binotalis Zell) dan Ulat Tritip (Plutella xylostella) pada Tanaman Sawi Hijau/Caisim (Brassica juncea). Skripsi. Universitas PGRI Yogyakarta.

Ningrum, P.T., Pujiati, R.S., Ellyke, \& Anita, D.M. (2015). Rendaman Daun Pepaya sebagai Pestisida Nabati untuk Pengendalian Hama Ulat Grayak (Spodoptera litura) pada Tanaman Cabai, hlm. 80-87. Prosiding Seminar Nasional Farmasi Jember. Current Challenges in Drug Use and Development Tantangan Terkini Perkembangan Obat dan Aplikasi Klinik. Jember 28 November 2015.

Pratiwi, N., Riza, A., Siti, R., Merdeka, P.I., \& Akhmad, R. 2011. Dampak penggunaan detergen sebagai pembersih pakaian dalam kehidupan. Banjarmasin (ID): Universitas Lambung Mangkurat.

Putrasamedja, S., Setiawati, W., Lukman, L., \& Hasyim, A. 2012. Penampilan beberapa klon Bawang merah dan hubungannya dengan intensitas serangan organisme pengganggu tumbuhan. Jurnal Hortikultura. 22(4): 349359 .

Ramadhona, R., Djamilah, Mukhtasar. (2018). Efektivitas Ekstrak Daun Pepaya dalam Pengendalian Kutu Daun pada Fase Vegetatif Tanaman Terung. Jurnal-Jurnal Ilmu Pertanian Indonesia. 20 (1): 1-7.

Sari, M., Lubis, L., \& Pangestiningsih, Y.Y. (2013). Uji efektivitas beberapa insektisida nabati untuk mengendalikan ulat grayak (Spodoptera litura F.) (Lepidoptera: Noctuide) di Laboratorium. Jurnal Online Agroteknologi. 1 (3) : 560-569.

Yuantari, M.G.C., Widianarko, B., \& Sunoko, H.R. 2016. Analisis Risiko Pajanan Pestisida Terhadap Kesehatan Petani. J. Kes. Mas. 10 (2): 239-245. 